\title{
Global Crisis and the Integration of India's Stock Market
}

\author{
Sarat Dhal \\ Reserve Bank of India
}

\begin{abstract}
Due to growing skepticism over the globalisation process across countries, economists in the emerging market economies (EMEs) are anxious to know how the integration of financial markets was associated with the recent global crisis and whether there could be some key lessons for the broader policy approach to the development of financial market in the future. In this milieu, this study emphasises on a positive perspective on the subject, deriving from the key concerns of the EMEs and the insights from the literature. Financial integration and its association with the global crisis could be construed in terms of the pricing and the re-pricing of risks by the markets. The study derives some crucial insights from the multivariate cointegration analysis of stock price indices for the global markets of the US, the UK and Japan and select regional markets such as Hong Kong, Singapore and India, with a focus on the latter, a leading emerging market economy. These markets shared a single cointegration relationship and the Indian market played the key role. The long-run integration was evident from stock prices measured in US dollar rather than local currencies, attributable to the role of foreign investors and capital flows. The analysis for the full sample and the subsample (excluding the crisis phase) showed that the global crisis could not have been associated with the breakdown of the long-run relationship among the markets. The cointegrated stock markets could contribute to financial stability, since stock prices cannot diverge too far from the long-run equilibrium path.
\end{abstract}

*Dr. Sarat Dhal: Department of Economic Analysis and Policy, Reserve Bank of India, Central Office, Mumbai, India, Tel: 91-22-22700937, Fax:91-22-22610769, e-mail: scdhal@rbi.org.in.

(2009-Center for International Economics, Sejong Institution, Sejong University, All Rights Reserved. 
Moreover, the risk pricing perspective on the subject could be useful for the EMEs to continue with the reform measures aimed at further strengthening of the integration process.

-JEL Classification: F36, F360, G1, G120, C100, C320

- Key Words: international economics, financial integration, financial markets, asset prices, econometrics and statistical models, time series models

\section{Introduction}

The recent global crisis, characterised with turbulent financial markets and widespread economic slowdown across the countries since the middle of 2007, has baffled economists with a volley of questions relating to the subject of international financial integration. What is the impact of the global crisis on the integration among financial markets? Whether the crisis could have weakened or strengthened integration among regional and global markets? Whether the impact of the crisis on financial integration could have long run and short-run perspectives? What policy lessons should countries derive for the development of financial markets in the future? From policy perspective, answers to these questions have assumed critical importance for all nations and more specifically for the emerging market economies (Watanagase (2008)). In this context, it is useful to begin with some of the principal concerns of the emerging market economies (EMEs) that motivated the present study.

First, recognising the various benefits of international integration (see Agenor (2001), Levine (2001), Prasad et al. (2003), Obsfeld (1998) among others), the EMEs significantly liberalised their trade and capital accounts of balance of payment, undertook a plethora of reform measures and adopted information technology enabled infrastructure for developing financial markets over the past two decades. In that process, stock markets emerged as a major channel for international integration, supported by a rapid increase in the cross-border mobility of private capital inflows due to investors seeking portfolio diversification and better yields, a growing reliance of nations on the savings of other nations and a shift in the leverage preference of companies to the equity financing from the debt financing. International financial integration helped the EMEs, inter alia, through financial development due to price discovery and enhanced market liquidity and 
most notably, a significant structural change in the financial intermediation process. The excessive dependence on domestic commercial banks for financing the growth needs of large and medium enterprises was moderated due to the increasing contribution of market-based financial intermediation. Illustratively, according to the World Federation of Exchanges, the number of companies listed in the stock markets across the globe more than doubled from 21,585 in 1990 to 46,706 in 2008. The bulk of this expansion came from the EMEs in the Asia-pacific region, as their listed companies increased from 6,330 to 20,819 during this period. The market capitalisation of the stock markets in this region surged from US dollar 3.5 trillion in 1990 to US dollar 19.8 trillion in 2007. The amount of capital raised by the listed companies in this region increased sharply from US dollar 58 billion to 341 billion during this period. However, the situation changed drastically as the global crisis originated from the sub-prime lending problems in an advanced economy like the US. The market capitalisation of stock markets in the AsiaPacific region plunged to US dollar 9.9 trillion in the year 2008, almost 50\% decline from the level witnessed in 2007. Also, the new capital issues in 2008 declined by 24.7 percent over 2007 , as against $31.4 \%$ average growth during 2003 07. Apart from the equity finance, stock market growth also facilitated several companies in the EMEs to meet their finance needs through corporate bonds and external commercial borrowings. Domestic banks, thus, catered to the growing requirements of agriculture and small and medium enterprises and the household sector through retail lending. However, due to the global crisis and the decline of international liquidity, large companies are now increasingly depending upon the domestic banking sector. In this context, it is perceived that any long-run weakening of the integration process could pose serious challenges to the EMEs, if they were to revert to the old bank-based financial system.

Second, a heartening aspect of the international integration of the EMEs was that reform and liberalisation measures in some countries like India were undertaken quite painstakingly through tedious political consensus building over the years. Backtracking from the open economy regime is perceived to be an extremely difficult process and it could prove costly for the nations. However, the voice of protectionism, that has gathered the momentum due to the current global crisis and in retrospect, various other crises in the past ranging from the Great Depression in the early 1930s to the crises in Asia, Eastern Europe and Latin America in the late 1990s, appears to be oblivious to this concern of the EMEs. Ironically, some of the advanced economies, which were lauding the beauty of globalisation and 
international integration, are now favouring protectionism and pursuing various inward looking policies, notwithstanding the multilateral initiatives for strengthening economic cooperation and policy coordination to tackle the crisis.

Third, it is perceived that the global crisis could be fuelling entirely a negative perspective on international integration, deviating from theoretical and applied perspectives. From a positive perspective, the global crisis could have occurred due to inappropriate risk pricing by financial markets for several reasons (Mohan (2009), Trichet (2009), Kunt and Serven (2009). Thus, the global crisis could have contributed to a correction in risk pricing and a better integration among the markets. Accordingly, it is felt that an assessment of the impact of the global crisis on the integration of financial markets consistent with theoretical and applied finance perspectives could provide crucial inputs for policy purposes.

In this milieu, the author is motivated for analysing international integration of the stock market of India, a leading emerging market economy. We have three principal objectives of the study while seeking answers to the above questions. First, we intend to provide a generalised perspective on the 'de facto' integration among global and regional markets before and after the global crisis. Thus, our study involves six stock markets, comprising the global markets of the US, UK, and Japan and the major regional markets of Asia pertaining to India, Hong Kong, and Singapore. Second, we focus on India's stock market, since several facts, discussed separately, suggested the growing international integration of Indian stock market during the reform period beginning the 1990s. However, studies on a formal analysis of India's integration is scarce and therefore, our study could prove useful for policy purposes. Third, the proof of pudding is in eating. Given our interest in the long-run versus short-run integration among financial markets, we use the vector error correction and cointegration model (VECM) in line with the dominant practice in the literature. We study integration meticulously, recognising various aspects of data and their implications for the robustness of the empirical findings. It may be noted that currently, there are early indications that the global crisis might be abating. Over the spell of two years, the global crisis has provided us a reasonable sample in terms of high frequency information, i.e., more than 500 daily and 100 weekly stock price data. This sample, coupled with historical data, could reflect on the impact of the crisis on the integration among stock markets. The remainder of the study is presented in four sections comprising the review of literature, the Indian context, empirical evidence and conclusion in order. 


\section{The Literature}

According to the literature, the integration of financial markets derives from various theoretical postulates including the law of one price owing to Cournot (1927) and Marshall (1930), the portfolio diversification with risky assets (Markowitz (1952)), the capital asset price model (Sharpe (1964), Lintner (1965)) and the arbitrage price theory (Ross (1976)). Despite distinguishing features, these theoretical models share a common perspective: if risks command the same price, then the correlation among financial asset prices and the linkage among the markets should come from the movement in the price of risks due to investors' risk aversion. Deriving from this generalised risk-pricing perspective, the empirical literature has surged with studies focused on measuring international integration using a variety of methodologies. ${ }^{1}$ However, following the seminal works of Engle and Granger (1987), Johansen (1988) and Johansen and Juselius (1990), numerous studies including Taylor and Tonks (1989), Kasa (1992), Masih and Masih (2002), Chowdhry (1994), Worthington and Higgs (2007) and Choudhry et al. (2007) have used the cointegration hypothesis to assess the international integration among financial markets. Until Taylor and Tonks (1989) and Kasa (1992), studies relied on correlation and regression analyses to gauge the nature of price convergence and international portfolio diversification across the markets (Levy and Sarnat (1970)), Agmon (1972), Solnik (1974) and Panton et al. (1976). Taylor and Tonks (1989) showed that the cointegration technique is useful from the perspective of the international capital asset price model. Kasa (1992) suggested that the shortterm return correlation between stock markets is not appropriate from the perspective of long-horizon investors driven by common stochastic trends. A cointegration model is useful since it not only distinguishes between the nature of long-run and short-run linkages among financial markets, but captures the interaction between them as well. Given the wide popularity of the cointegration model, we refrain from rehashing its technical aspects. What is striking about the numerous studies is that apart from the risk pricing aspect, they provide some useful insights about the benefits of integration among the stock markets relating to price equalisation, market equilibrium, market efficiency and portfolio diversification (Choudhry et al. (2007)).

'These include correlation, regression, vector autoregression (VAR), vector error correction and cointegration (VECM), generalised autoregressive conditional heteroscedacity (GARCH) models. 
First, the evidence of cointegration among national stock indices implies equilibrium constraints and precludes stock indices diverging too much from the long run path. Such constraints could emerge due to common stochastic trends or driving forces underlying their mutual growth over extended time horizons (Gonzalo and Granger (1995)) and the exposure of markets to similar risk factors and a common risk premium (Ahlgren and Antell (2002)). The cointegration results could have implications for the stability of financial markets (Johansen and Juselius (1990), Dickey et al. (1991)). Also, the existence of cointegration relation could be consistent with the multifactor international capital asset pricing model (Bachman et al. (1996)).

Second, studies on the cointegration of stock markets have contested the efficient market hypothesis (EMH). According to this hypothesis, the changes in asset prices in efficient markets cannot be predicted. In cointegration models, however, deviations of prices from a long-run relationship indicate predictable future price changes (Granger (1992), Baillie and Bollerslev (1989) and Hakkio and Rush (1989)). Diverging from this viewpoint, Dwyer and Wallace (1992), Crowder and Wohar (1998) and Masih and Masih $(1997,2002)$ argue that there is no general equivalence between the market efficiency and the lack of a long-run relationship between assets. Dwyer and Wallace (1992) define market efficiency as the lack of arbitrage opportunities. Hassan and Naka (1996) suggest that in cointegrated markets, price movements in one market immediately influence other markets, consistent with efficient information sharing and free access to markets by domestic and foreign investors. Harvey (1995) and Korajczyk and Vallet (1989) suggest that the improvement in market efficiency is consistent with increasing integration with world markets. If markets are predictable and foreign investors are sophisticated, then investors are likely to profit from the predictability of returns. As foreign investors take advantage of market inefficiencies, those market inefficiencies will decrease and prices will react more quickly to new information (Kim and Singhal (2000)). Another viewpoint is that national stock markets are different since they operate in the economic and social environments of different countries. Accordingly, a country's financial market functions efficiently when prices reflect the fundamentals and risks of that country, rather than the fundamentals and risks of other countries. However, financial integration could occur due to real economic interdependence or linkages among economic fundamentals across the nations. For instance, the profit and loss account and the balance sheet of a domestic company relying on a large volume of exports and 
imports can be affected by the financial and macroeconomic developments in other countries.

Third, from the perspective of portfolio diversification, some economists recognise that cointegrated stock markets weaken the international portfolio diversification in the long run (Choudhry et al. (2007), Kearney and Lucey (2004)). This is because the existence of common factors limits the amount of independent variation in stock prices (Chen et al. (2002)). Another view is that portfolio diversification benefits would accrue in the short run but not in the long run (Hassan and Naka (1996)). Byers and Peel (1993) argue that cointegration among stock prices does not preclude the benefits of diversification, since these follow from the covariance of stock returns rather than from the covariance of prices. Similarly, Hakkio and Rush (1991) and Sephton and Larsen (1991) have questioned the reliability of using the cointegration hypothesis to test market efficiency and portfolio diversification. Verchenko (2000) argues that the extent of portfolio diversification in cointegrated markets could depend upon the size of the coefficients of the long-run cointegrating vector(s) relating to various stock price indices. In our view, the cointegration vector can be consistent with the standard asset demand function, for which the price of one asset (domestic) depends on other regional and global assets, some of which may serve as substitutes or complements to domestic assets. Thus, portfolio diversification in the long run would depend on the size and the sign of the coefficients of the cointegration vector relating to various stock prices.

\section{The Indian Context}

Until the early 1990s, India's financial system was regulated, relying heavily on a bank-based system for financial intermediation under the aegis of the public sector. There were several restrictions on the transactions relating to the balance of payment (BOP), coupled with the exchange rate pegged to major currencies. Financial markets lacked depth in the absence of adequate instruments and competitive pricing mechanism. Though the stock market existed for long, it hardly catered to the saving needs of households and the investment needs of the companies. Thus, its growth was almost stunted. In the wake of BOP crisis in

\footnotetext{
${ }^{2}$ The Ministry of Commerce and Industry, Government of India provides details about all the trade agreements which have been concluded and the agreements, which are on the pipeline in its website: http://commerce.nic.in .
} 
1991, India embraced reform with exclusive focus on the financial sector. Exchange rate was allowed to be market driven in 1993. Different segments of financial markets relating to treasury securities, credit, foreign exchange, equities and insurance were developed. The non-debt capital flows comprising the foreign direct investment (FDI) and portfolio investment flows were specifically encouraged. India also engaged with trade and economic cooperation agreements with several countries and regional groups across Asia, Europe, America and Western hemisphere to strengthen its international integration. ${ }^{2}$

Of particular interest to the stock market, the reform measures aimed at creating growth-enabling institutions, boosting competitive conditions, putting in place an appropriate regulatory framework, reducing information asymmetry and transaction costs, and thereby boosting the investor confidence. FDI was allowed to the extent of $100 \%$ for several manufacturing activities. Foreign institutional investors (FIIs) were allowed to participate in the capital market. The Indian companies were allowed to raise funds from abroad through the American/Global Depository Receipts (ADRs/ GDRs), foreign currency convertible bonds (FCCBs) and external commercial borrowings (ECBs). A regulator body for the capital market, namely, the Securities and Exchange Board of India, was set up. The National Stock Exchange of India was set up with a view to provide competition to the existing Bombay Stock Exchange of India. With the repeal of the capital issues (control) act, 1947, companies were given freedom to price their issues. The bookbuilding process in the new issue of capital was introduced with a view to strengthen the price discovery process. In the secondary market, the floor-based open outcry trading system was replaced by electronic trading system. The account period settlement system was replaced by the rolling settlement in line with the international practice to contain speculation. This process was enabled by a shift to electronic book entry transfer system through depository mechanism. A comprehensive risk management system was put in place with trading members subject to margins based on trading volumes and various other parameters and exposure norms. The mark-to-market margin system based on value at risk was introduced to capture the risk profile of trading members. For providing market participants the instruments for hedging and risk management, several types of derivative products on equities were introduced. For strengthening the process of information flows from the listed companies, sufficient disclosures were made mandatory for the companies at the stage of public issue and in its aftermath. The decisions pertaining to dividend, bonus and right announcements or any material 
event were required to be disclosed to the public within 15 minutes of the conclusion of the companies' board meetings. The accounting practices were streamlined with norms introduced for segment reporting, related party transactions and consolidated balance sheets. Insider trading was made a criminal offence. The regulations governing substantial acquisition of shares and takeovers of companies were introduced, aiming at protecting minority shareholders and making the takeover process more transparent.

Reflecting the impact of reform, India's stock market grew rapidly during the reform period. The Bombay Stock Exchange (BSE) emerged as the largest stock exchange in the world in terms of the number of listed companies, comprising many large, medium-sized and small firms. The share price index grew by an average $25.0 \%$ annually in nominal terms and $19.0 \%$ in real terms during 1991 2008 , as compared with nominal and real growth rates of $7.6 \%$ and $1.4 \%$ during the fifty-year period 1950-1989. With a market capitalisation of US $\$ 1.8$ trillion in 2007, the BSE became the tenth largest stock exchange in the world and compared with advanced economies in terms of the ratio of market capitalisation to gross domestic product. With the objective of internationalisation, several Indian companies opted for listing on the stock exchanges of other countries, especially the United States and United Kingdom. Ten major Indian companies listed on the New York Stock Exchange (NYSE) account for a 19\% weight in the benchmark 30 -scrip stock price index of the BSE. With the rapid growth, the stock market catered to the needs of saving households and investors. The share of equities in household saving stood at $10.5 \%$ in 2008 , a sharp increase from average $2.7 \%$ during the 1970 s to 1980 s. On cumulative basis, the new capital issues by nongovernment public limited companies increased sharply to Rupees 2,760 billion during 1990 to 2008 from Rupees 201 billion during the 1970s to 1980s.

Foreign investment inflows played a crucial role in the growth of India's stock market. The annual FDI inflows increased from a modest US dollar 4 billion, on average, during 1995-2005 to US dollar 35 billion in 2008, as the Indian economy moved to a high growth trajectory at $8.5 \%$ during $2003-2008$ from the average growth rates at 3.5 to $4 \%, 5.8 \%$ and $6.4 \%$ during the $1950 \mathrm{~s}$ to $1970 \mathrm{~s}$, the $1980 \mathrm{~s}$ and the 1990s, respectively. The value of portfolio investment inflows to India surged from US dollar 14.8 billion in 1997 to US \$ 21 billion in 2002 and US \$ 333 billion in $2007^{3}$, spurred by attractive return in the Indian stock market. The annual

\footnotetext{
${ }^{3}$ The portfolio investment data reported here refers to the Coordinated Portfolio Investment Survey of the International Monetary Fund. It is in line with the stock (market value) of cumulative inflows over the years rather than the nominal annual flow measure.
} 
stock return in US dollar terms averaged 32\% during April 2002 to January 18, 2008, much higher than the global and regional markets such as the US (7.4\%), UK (9.6\%), Japan (7.4\%), Hong Kong (13.0\%), and Singapore (14.5\%). In terms of risk adjusted return too, the Indian stock market outperformed other markets. Thus, India became a major destination, representing about a fourth of total portfolio capital inflows to the EMEs group. In 2008, there were as many as 1,500 foreign institutional investors participating in the India's stock market. The purchase and sales activities of such investors accounted for three fourths of the average daily turnover in the India's stock market. Since foreign investors operate in a number of countries at the same time, their operations can be expected to have contributed to the integration of the Indian stock market with other markets.

With respect to the global and regional stock markets studied, comprising the US, UK, Japan, Singapore and Hong Kong, India had a significant trade and financial relations with these countries. Illustratively, these five countries were among the top ten sources for portfolio investment inflows to India and accounted for US \$ 136 billion or 41\% of India's total portfolio investment inflows at US \$ 333 billion by the end of 2007. Also, these countries together accounted for about a fourth of India's total merchandise trade. The US continued to be India's single largest trade partner, until China overtook this position a year ago. However, the US remains the second largest source of portfolio investment flows, accounting for $26 \%$ total portfolio investment inflows to India in 2007-08. With the UK, India has a long-standing trade and financial relations since the colonial rule. It accounted for $3 \%$ of India's merchandise trade in 2008. It was the fourth largest source of portfolio investment inflows in 2007, with a share of 7.0\% in India's portfolio investment inflows. As regards regional markets in Asia, India's trade relation showed significant improvement during the reform period. With Singapore, India signed a comprehensive economic cooperation agreement in 2004-05. India's trade relation with Singapore more than doubled from $2 \%$ in the early 1990 s to $4 \%$ in 2008. It was the fifth largest source of portfolio investment inflows to India, with $4.4 \%$ of India's total investment flows. Similarly, India also showed significant improvement in trade and investment relations with the Hong Kong. Anecdotal evidence shows that about 1,500 Indian companies and seven Indian banks had a business presence in Hong Kong. The Hong Kong market is also the major financial centre in China and the Asian region, with which India has witnessed the rapid growth of trade in recent years. Recently, efforts have been initiated for free trade and double taxation avoidance agreements between India and Hong Kong. 
The following section shows whether the plethora of reform initiatives and stylised facts contributed to the formal integration of the Indian stock market in terms of price comovement!

\section{The Empirical Evidence}

According to the empirical literature, the cointegration among stock prices could be subject to three major aspects of data relating to the frequency, the currency denomination and the sample period. Thus, a set of caveats are in order. First, studies prefer high-frequency daily and weekly data to monthly and quarterly data, deriving justification from speedy transmission of information and synchronous trading made possible by the information technology enabled online trading platform and payment and settlement systems capture (Voronkova (2004), Hassan and Naka (1996), Cha and Oh (2000)). Monthly and quarterly data are useful, since economic fundamentals including output, inflation and dividends, which are considered to be the key drivers of stock prices, are mostly available in these frequencies (Blackman et al. (1994), Masih and Masih (2002)). Secondly, studies use stock prices measured in a common reference currency, typically, the US dollar, recognising the latter's role of a major invoicing currency for global trade and investment activities, and the portfolio diversification and arbitrage activities of dominant market participants such as foreign investors (Bachman et al. (1996), Renatas and Christian (2006), Hilliard (1979), Meric and Meric (1989), Philippatos et al. (1983)). Some studies also preferred to using stock prices in domestic currency units with the argument that these indices restrict their change to movements in security prices and avoid distorting the empirical results with sharp devaluation of the exchange rates, especially during the periods of crisis (Choudhry et al. (2007)). Thirdly, for analysing the long-run integration among markets, it is appropriate to use a long sample period comprising several years rather than large sample observations with high frequency daily or weekly data for a few years (Hakkio and Rush (1991)). However, over a very long horizon such as a decade or more, the long-run integration of markets may be affected by structural shifts emanating from changes in the policy regime and the general economic environment.

With the above issues, we use six stock price indices: the 200-scrip index of the BSE of India, two stock price indices relating to regional markets such as Singapore and Hong Kong, and three stock price indices relating to global markets 
in the United States, the United Kingdom and Japan, as defined in the Annex. We use stock price indices measured in local currency as well as the US dollar. The cointegration analysis is based on stock price indices in their natural logarithm transformation. As regards the frequency of data, we used daily as well as weekly stock price indices over the period covers April 1993 to July 2009. Second, we estimated the cointegration model for two sample periods i.e., the full sample from April 1993 to July 2009 and a restricted sample from April 1993 to January 18, 2008. While the first sample included the current global crisis, the second one excluded it.

\section{A. The Unit Root Test}

Results from the Augmented Dickey-Fuller (ADF) and Philips-Perron (PP) tests suggested that the daily and weekly stock price indices measured in the US dollar and local currency units were non-stationary in their natural logarithm level, with the deterministic trend including the intercept and the time trend components. In the first difference form, however, these stock price indices were stationary,

Table 1. Unit Root Test of Weekly Stock Prices

\begin{tabular}{lcccc}
\hline & \multicolumn{2}{c}{$\begin{array}{c}\text { Level Form } \\
\text { (with intercept and trend ) }\end{array}$} & \multicolumn{2}{c}{$\begin{array}{c}\text { First Difference Form } \\
\text { (with intercept) }\end{array}$} \\
\hline Indices & ADF Test & PP Test & ADF Test & PP Test \\
\hline US Dollar Denominated & & & & \\
\hline LBSE & -1.45 & -1.57 & -57.60 & -58.20 \\
LSNG & -1.83 & -1.82 & -57.16 & -57.17 \\
LHNK & -2.38 & -2.46 & -62.17 & -62.21 \\
LJP & -2.09 & -1.93 & -64.84 & -65.08 \\
LUK & -0.74 & -0.92 & -30.10 & -65.46 \\
LUS & -0.76 & -0.73 & -49.78 & -68.13 \\
\hline Domestic Currency Denominated & & & & \\
\hline LBSE & -1.69 & -1.64 & -24.35 & -24.44 \\
LSNG & -2.11 & -2.10 & -24.09 & -24.14 \\
LHNK & -2.81 & -2.75 & -23.69 & -23.69 \\
LJP & -2.18 & -2.11 & -24.46 & -24.49 \\
LUK & -2.00 & -1.87 & -24.74 & -24.75 \\
LUS & -1.13 & -1.13 & -25.42 & -25.54 \\
\hline
\end{tabular}

Note: $1 \%, 5 \%$ and $10 \%$ critical value for $\mathrm{ADF}$ and PP tests with intercept and trend are $-3.97,-3.41$ and -3.13 , respectively and the $1 \%, 5 \%$ and $10 \%$ critical value for ADF and PP tests with intercept, are $-3.44,-2.86$ and -2.57 , respectively. The ADF regression model was based on SIC lags, which in most cases varied from 1 to 3 weeks. The PP test was based on Bartlett-kernel spectral estimation using Newey-West bandwidth. 
plausibly with an intercept-only trend component (Table 1). Thus, the chosen stock price indicators were found to be first-order integrated or I(1) processes. Accordingly, it was useful to investigate whether they might be cointegrated.

\section{B. Lag Selection}

For the estimation of Johansen and Juselius (1990) type VECM, the unrestricted vector autoregression (VAR) model was first estimated and the common lag length ascertained from various information criteria such as Swartz-Bayes criteria (SBC), Hannan and Quinn criteria (HQC), the final prediction error criteria (FPE), and the Akaike information criteria (AIC). For the VAR model involving daily stock prices, the SBC and HQC showed a lower-order lag length of two or three days. On the other hand, the FPE and AIC determined a somewhat higher six to elevenday lag length. For the weekly data, the FPE and AIC suggested three/four lags, while the SBC and HQC suggested two/three lags. For high-frequency time series, empirical studies generally preferred lower lags, bearing in mind the informational efficiency of stock markets (Schollhamer and Sand (1987)), Eun and Shim (1989), Hassan and Naka (1996)). However, we found that the residuals from the VECM model based on daily data with 2 or 3 lags were not free from serial autocorrelation. We could increase the lag length upto 11-days for making the residuals serially uncorrelated. Also, we found that a higher lag length did not affect the number of cointegration vectors. For the weekly data, the VECM with 23 lags was able to yield in residuals free from autocorrelation problem. Furthermore, the coefficients of the long-run cointegration vector involving daily data with 11 lags were more or less similar to the weekly data with 2-3 lags. Thus, we restrict our discussion to the VECM based on weekly data.

\section{Cointegration Rank Test}

The cointegration rank tests suggested two broad findings on the evidence of stock market integration. First, the currency denomination of stock prices played an important role. Stock price indices measured in US dollars rather than local currencies were cointegrated. For the former, both the trace and the maximum eigen value tests supported a single cointegration relation with the linear trend component comprising the intercept and the time trend for the long sample covering April 1993 to July 2009 as well as the sample excluding the global crisis period, i.e., April 1993 to January 18, 2008 (Table 2). This finding compared with Bachman et al. (1996), Renatas and Christian (2006), Hilliard (1979), Meric and 
Table 2. Cointegration Rank: Summary

\begin{tabular}{ccccc}
\hline & \multicolumn{2}{c}{ No Deterministic Trend } & \multicolumn{2}{c}{ Linear Trend } \\
\hline Test Type & $\begin{array}{c}\text { No Intercept and } \\
\text { trend in CE and } \\
\text { VAR }\end{array}$ & $\begin{array}{c}\text { Intercept in CE } \\
\text { and no intercept } \\
\text { in VAR }\end{array}$ & $\begin{array}{c}\text { Intercept in CE } \\
\text { and VAR }\end{array}$ & $\begin{array}{c}\text { Intercept and trend in } \\
\text { CE and no trend in } \\
\text { VAR }\end{array}$ \\
\hline Daily Stock Prices in US dollar with 2 to 11-day lags in the VECM \\
\hline Trace & 0 & 0 & 0 & 1 \\
Max-Eigen Value & 0 & 0 & 0 & 1 \\
\hline Daily Stock Prices in Local currency, with 2 to 11 day lags in the VECM \\
\hline Trace & 0 & 0 & 0 & 0 \\
Max-Eigen Value & 0 & 0 & 0 & 0 \\
\hline Weekly Stock Prices in US dollar with two or three lags in the VECM \\
\hline Trace & 0 & 0 & 0 & 1 \\
Max-Eigen Value & 0 & 0 & 0 & 1 \\
\hline Weekly Stock Prices in Local currency with two or three lags in the VECM \\
\hline Trace
\end{tabular}

Meric (1989), and Philippatos et al. (1983). However, the lack of integration among stock prices measured in local currencies raised a concern echoed by Choudhry et al. (2007).

Second, the existence of a single cointegration relation among the stock price indices in US dollars espoused a concern that not all regional and global stock price indicators could be critical for the long run integration among the markets. Thus, we investigated (i) the bivariate cointegration relation involving the Indian stock price on the one hand and each of the five regional and global stock prices on the other hand and (ii) multivariate cointegration relation involving alternative combinations of regional and global stock prices with or without India (Table 3). It was evident that the Indian stock market did not show bivariate cointegration with any of the five regional and global stock markets. In terms of multivariate cointegration, there was no evidence of cointegration among regional markets involving India, Hong Kong, and Singapore. Even the inclusion of Japan into this combination did not matter. Also, the Asian markets comprising the Hong Kong, Singapore and Japan were not cointegrated. However, a single cointegration relation was evident among the stock markets of India, the US and UK. This cointegration was not due to the cointegration between the two global markets, i.e., the US and UK. Thus, the Indian stock market played a critical role for the integration among regional and global markets. Notwithstanding these results, it 
Table 3. Cointegration Rank: Alternative Combinations of Stock Prices

\begin{tabular}{lccc}
\hline Pairs of Stock Price Indices & $\begin{array}{c}\text { Whether } \\
\text { Cointegrated } \\
\text { (Reject/Accept) }\end{array}$ & $\begin{array}{c}\text { Trend Type } \\
\text { (A,B,C,D) }\end{array}$ & $\begin{array}{c}\text { Number of } \\
\text { Cointegration } \\
\text { Relations }\end{array}$ \\
\hline LBSE,LHNK & Reject & A,B,C,D & 0 \\
LBSE,LSNG & Reject & A,B,C,D & 0 \\
LBSE,LJP & Reject & A,B,C,D & 0 \\
LBSE,UK & Reject & A,B,C,D & 0 \\
LBSE,LUS & Reject & A,B,C,D & 0 \\
LBSE,LHNK,LSNG & Reject & A,B,C,D & 0 \\
LBSE,LHNK,LSNG,LJP & Reject & A,B,C,D & 0 \\
LUK,LUS & Reject & A,B,C,D & 0 \\
LHNK,LSNG,LJP & Reject & A,B,C,D & 0 \\
LHNK,LSNG,LJP, LUK,LUS & Reject & A,B,C,D & 0 \\
LBSE,LUK,LUS & Accept & D & 1 \\
LBSE,LHNK,LSNG,LJP,LUK,LUS & Accept & D & 1 \\
\hline
\end{tabular}

Note: Trend types are as follows: No deterministic trends are A: No Intercept or trend in the cointegration equation (CE) and test VAR and B: Intercept (no trend) in CE and no intercept in VAR; Linear Trends are C: Intercept (no trend) in CE and test VAR and D: Intercept and trend in CE and notrend in VAR

was found that regional markets in Asia were not redundant in the long-run cointegration relation as they were not associated with insignificant coefficients (Table $4 \& 5$ ). Also, the likelihood ratio (LR) test for the null hypothesis of zero restriction on the coefficients of regional markets taken individually or in pairs of them yielded a highly statistically significant chi-square $\chi^{2}$ statistic, thus, validating the long-run causal impact of these markets on the Indian market.

\section{Long-Run Cointegration}

Since our interest was in the Indian market vis-à-vis the global and the regional markets, we estimated the cointegration vector normalised to India's stock price (Table 4) for the full sample (1993-2009) and (Table 5) the sub-sample (19932008). The estimated coefficients of the long-run cointegration vector provided various insights. First, the coefficients of regional and global stock price indices in the cointegration relation did not have similar signs. Hong Kong and Japan had the positive coefficient while Singapore had the negative coefficient. Similarly, the coefficients of the global markets, i.e., the US and UK, were opposite to each other. This finding could be attributable to investors' long-run portfolio diversification objective due to the differential risks associated with global and regional markets relative to the Indian market. Also, the domestic market could be differentially 
Table 4. Long-run Cointegration Relation ( April 1993 to July 2009, Weekly Stock Prices in US Dollar)

\begin{tabular}{cccccc}
\hline LBSE\$ & 1.000000 & 1.000000 & 1.000000 & 1.000000 & 1.000000 \\
LHNK\$ & -1.2407 & 0 & -0.7263 & -1.6178 & 0 \\
& $(-5.83)$ & & $(-5.35)$ & $(-6.34)$ & \\
LSNG\$ & 0.4451 & -0.0436 & 0 & 0.4454 & 0 \\
& $(2.99)$ & $(-0.35)^{*}$ & & $(2.50)$ & \\
LJP\$ & -0.4353 & -0.7451 & -0.3645 & 0 & 0 \\
& $(-3.39)$ & $(-4.40)$ & $(-2.82)$ & & \\
LUK\$ & -3.7438 & -3.9411 & -3.4277 & -3.9663 & -5.9019 \\
& $(-11.47)$ & $(-9.01)$ & $-10.81)$ & $(-10.14)$ & $(-11.41)$ \\
LUS\$ & 4.5296 & 4.3599 & 3.9150 & 4.7709 & 6.2101 \\
& $(13.17)$ & $(10.01)$ & $(13.32)$ & $(11.48)$ & $(11.57)$ \\
TREND & -0.0033 & -0.0040 & -0.0033 & -0.0030 & -0.0046 \\
& $(-17.92)$ & $(-17.05)$ & $(-17.31)$ & $(-13.69)$ & $(-12.87)$ \\
Intercept & -2.2409 & -2.5587 & -1.7563 & -2.5748 & -5.6351 \\
Zero Restriction on the Coeffi- & & $16.83(0.00)$ & $7.03(0.01)$ & $6.26(0.01)$ & $30.04(0.00)$ \\
cients of Regional Markets ${ }^{* *}$ & & & & & \\
\hline
\end{tabular}

Figures in parentheses indicate asymptotic ' $t$ ' statistic.

* Not significant at $5 \%$ level.

${ }^{* *}$ LR test refers to $\chi^{2}$ (1) statistic (level of significance) in the $2^{\text {nd }}, 3^{\text {rd }}, 4^{\text {th }}$ columns and $\chi^{2}$ (3) statistic in the last column.

linked with global markets such as the US and UK providing competing portfolio choices for investors. Second, in absolute terms, the coefficients of two global markets, the US and UK, were substantially higher than those of regional markets such as Singapore and Hong Kong. Third, among the Asian markets, the coefficients of Singapore and Japan were similar in magnitude but in the opposite direction, thus, leaving the Hong Kong market to be associated with the positive impact on the Indian market. Fourth, the LR test indicated that the unity restriction on the sum of the coefficients pertaining to the US and UK markets could not be rejected. Thus, a percentage point increase in the US and UK stock prices could have similar impact on India.

Table 5 provides the estimates of the long-run cointegration vector for the period excluding the global crisis. A comparison between Table 4 and Table 5 provides a key insight about the impact of the global crisis on financial integration. The longrun coefficients showed moderation, albeit, marginally, due to the impact of the global crisis. 
Table 5. Long-run Cointegration Relation (April 1993 to January 18, 2008, Weekly Data, Stock Prices in US Dollar

\begin{tabular}{cccccc}
\hline LBSE\$ & 1 & 1 & 1 & 1 & 1 \\
LHNK\$ & -1.2804 & 0 & -0.7361 & -1.6981 & 0 \\
& {$[-6.24]$} & & {$[-5.17]$} & {$[-6.54]$} & \\
LSNG\$ & 0.5224 & 0.0214 & 0 & 0.5014 & 0 \\
& {$[3.61]$} & {$[0.16]$} & & {$[2.75]$} & \\
LJP\$ & -0.4783 & -0.7962 & -0.3559 & 0 & 0 \\
LUK\$ & {$[-3.87]$} & {$[-4.62]$} & {$[-2.70]$} & & -6.0401 \\
LUS\$ & -3.7344 & -4.0332 & -3.4245 & -3.9575 & {$[-10.67]$} \\
& {$[-12.19]$} & {$[-9.27]$} & {$[-10.80]$} & {$[-10.22]$} & 6.5133 \\
TREND & 4.6730 & 4.5478 & 4.0689 & 4.9439 & {$[10.90]$} \\
& {$[14.04]$} & {$[10.29]$} & {$[13.30]$} & {$[11.67]$} & -0.0049 \\
Intercept & -0.0035 & -0.0042 & -0.0035 & -0.0033 & {$[-10.37]$} \\
Zero Restriction on & {$[-17.53]$} & {$[-14.94]$} & {$[-15.80]$} & {$[-12.73]$} & -6.3960 \\
the Coefficients of & -2.9346 & -3.0849 & -2.1912 & -3.2998 & \\
Regional Markets & & & & & \\
\hline
\end{tabular}

Figures in parentheses indicate asymptotic ' $t$ ' statistic.

* Not significant at $5 \%$ level.

${ }^{* *}$ LR test refers to $\chi^{2}(1)$ statistic (level of significance) in the $2^{\text {nd }}, 3^{\text {rd }}, 4^{\text {th }}$ columns and $\chi^{2}(3)$ statistic in the last column.

\section{E. Short-Run Market Linkage}

The nature of short-run integration of stock markets was evident from the coefficient of the error correction term in the VECM error correction equations pertaining to the six stock price indices (Table 6). Since the cointegration relation is identified with the Indian stock market, the error correction term could represent the deviation of the Indian market from the long-run path. In the full sample error correction model, the US, UK, Hong Kong, and Singapore markets exhibited an inverse response, whereas the Japanese market a positive response to the error correction term. Between the two sample periods, only, the Hong Kong market showed a sign change in the coefficient of error correction term. The coefficient of the error correction term also provided another important insight about the speed of adjustment of stock markets to the underlying long-run equilibrium path. About 3 quarters were required by the Indian market to revert to its potential long-run trend path in the full sample model; thus, one quarter improvement over the restricted 
Table 6. Error Correction Dynamics and Short-run Adjustment

\begin{tabular}{|c|c|c|c|c|c|c|}
\hline $\begin{array}{l}\text { Coefficient of the } \\
\text { Error Correction } \\
\text { Term (ECM) }\end{array}$ & LBSE & LHNK & LSNG & LJP & LUK & LUS \\
\hline \multicolumn{7}{|c|}{ Full Sample April 1993-July 2009} \\
\hline ECM & -0.02955 & -0.00741 & -0.01714 & 0.012339 & -0.00581 & -0.02183 \\
\hline SE & -0.00951 & -0.00804 & -0.00828 & -0.00645 & -0.00553 & -0.00516 \\
\hline$t^{\prime}$ stat & -3.10800 & $-0.92117^{*}$ & -2.07005 & 1.91289 & $-1.05075^{*}$ & -4.23340 \\
\hline \multicolumn{7}{|c|}{ Restricted Sample April 1993 to January 2008} \\
\hline ECM & -0.01966 & 0.00283 & -0.01376 & 0.01698 & -0.00090 & -0.01798 \\
\hline SE & -0.00913 & -0.00835 & -0.00854 & -0.00687 & -0.00485 & -0.00466 \\
\hline$t^{\prime}$ stat & -2.15346 & $0.33854^{*}$ & $-1.61038^{*}$ & 2.47195 & $-0.18561^{*}$ & -3.85858 \\
\hline $\begin{array}{l}\text { Percent Increase in } \\
\text { the ECM between } \\
\text { the periods }\end{array}$ & 50.31 & 162.12 & 24.57 & -27.34 & 544.95 & 21.39 \\
\hline \multicolumn{7}{|c|}{ Speed of adjustment (number of weeks) } \\
\hline Full sample & 34 & 135 & 58 & 81 & 172 & 46 \\
\hline Restricted sample & 51 & 354 & 73 & 59 & 1110 & 56 \\
\hline
\end{tabular}

SE: Standard error; the variables are in the first difference form in ECM

${ }^{*}$ Not significant at $5 \%$ level.

sample. The short-run adjustment of regional markets in the more recent period was not statistically significant, in contrast to the significant effect of the cointegration relation, implying that India's integration with regional markets is of a long-run rather than a short-run nature in the more recent period.

\section{F. Structural Break and Sample Sensitivity}

Whether the global crisis could have caused a structural break in the comovement of India's stock price with regional and global markets? In this regard, we used the Quandt-Andrew unknown break point test for the least square regression of the Indian stock price with regional and global stock prices and the intercept and the time trend as the explanatory variables. Interestingly, we found that a break point could have occurred in the middle of July 2002, rather than any time during the recent global crisis. After ascertaining the break point, we further investigated whether the long-run cointegration relation for the sample beginning from the break point July 12, 2002 to July 2009 with the global crisis and July 12, 2002 to January 18, 2008 (without the global crisis) could be different from our earlier estimates for the periods beginning from April 1993. We still found the single cointegration relation binding upon the six markets for the period beginning from July 2002. For the global markets, the US, UK, and Japan, their associated 
Table 7. Long-run Cointegration Relation

\begin{tabular}{ccccc}
\hline & $\begin{array}{c}\text { April 1993 to July } \\
2009\end{array}$ & $\begin{array}{c}\text { April 1993 to Janu- } \\
\text { ary 18, 2008 }\end{array}$ & $\begin{array}{c}\text { July 12, 2002 to } \\
\text { July 2009 }\end{array}$ & $\begin{array}{c}\text { July 12, 2002 to } \\
\text { January 18, 2008 }\end{array}$ \\
\hline LBSE\$ & 1 & 1 & 1 & 1 \\
LHNK\$ & -1.2407 & -1.2804 & -1.7166 & -1.3921 \\
& $(-5.83243)$ & $(-6.23629)$ & $(-6.10194)$ & $(-5.06919)$ \\
LSNG\$ & 0.445113 & 0.522353 & 0.9065 & 1.0292 \\
& $(2.98930)$ & $(3.61142)$ & $(3.08985)$ & $(3.89388)$ \\
LJP\$ & -0.4353 & -0.4783 & 0.3019 & 0.7895 \\
& $(-3.38594)$ & $(-3.86696)$ & $(1.55957)$ & $(4.26935)$ \\
LUK\$ & -3.7438 & -3.7344 & 3.4366 & 3.9444 \\
& $(-11.4686)$ & $(-12.1887)$ & $(5.63445)$ & $(6.41833)$ \\
LUS\$ & 4.529573 & 4.672962 & -5.3940 & -7.8842 \\
& $(13.1662)$ & $(14.0362)$ & $(-6.86785)$ & $(-9.03003)$ \\
TREND & -0.0033 & -0.0035 & -0.0016 & 0.0001 \\
& $(-17.9242)$ & $(-17.5348)$ & $(-5.51739)$ & $(0.13664)$ \\
Intercept & -2.2409 & -2.9346 & 10.8517 & 16.5412
\end{tabular}

Figures in parentheses are asymptotic ' $t$ ' statistic. ${ }^{*}$ refers to insignificant coefficients

long-run coefficients for the period beginning from the July 12, 2002 showed a sign change as compared with the long sample beginning from April 1993. On the other hand, regional markets, Hong Kong and Singapore did not show any sign change in their coefficients. The size of long run coefficients associated with Hong Kong and Singapore was much higher for the recent period than the long sample period, thus, suggesting a strengthening of India's regional integration. For the three global markets, there could have been a weakening of their long-run relationship with India due to the global crisis. The error correction model, however, did not show any significant change in the markets' short-run adjustment to the long-run path due to the global crisis phase.

\section{G.Variance Decomposition Analysis}

The forecast error variance decomposition analysis arising from the VECM model of stock prices constitutes an important tool for gauging the importance of innovations in one market for the other markets or the nature volatility transmission across markets (Chen et al. (2002)). In our case, these results from the VECM involving weekly stock prices in US dollar for the full sample (including the crisis phase) and the restricted sample (excluding the crisis phase) over a week, month (4-week), quarterly (12-week), annual (52-weeky) and the medium term (3year or 150 week) horizons are summarised in Table 8 . For the sample period 
Table 8A. Variance Decomposition: April 1993 to July 2009

\begin{tabular}{|c|c|c|c|c|c|c|c|}
\hline \multicolumn{8}{|c|}{ Variance Decomposition of LBSE } \\
\hline Period & S.E. & LBSE & LHNK & LSNG & LJP & LUK & LUS \\
\hline 1 & 0.0 & 77.1 & 2.9 & 0.6 & 1.3 & 4.6 & 13.5 \\
\hline 4 & 0.1 & 60.7 & 4.8 & 0.2 & 2.1 & 7.4 & 24.7 \\
\hline 12 & 0.2 & 42.3 & 10.3 & 0.1 & 2.4 & 15.8 & 29.1 \\
\hline 52 & 0.3 & 26.6 & 15.7 & 0.3 & 3.9 & 29.6 & 23.9 \\
\hline 150 & 0.6 & 22.6 & 17.1 & 0.4 & 4.3 & 33.4 & 22.1 \\
\hline \multicolumn{8}{|c|}{ Variance Decomposition of LHNK: } \\
\hline Period & S.E. & LBSE & LHNK & LSNG & LJP & LUK & LUS \\
\hline 1 & 0.0 & 0.0 & 58.6 & 0.0 & 2.9 & 5.0 & 33.5 \\
\hline 4 & 0.1 & 0.9 & 49.5 & 0.0 & 3.4 & 6.3 & 39.9 \\
\hline 12 & 0.1 & 2.2 & 46.3 & 0.0 & 3.8 & 7.6 & 40.1 \\
\hline 52 & 0.3 & 3.2 & 45.6 & 0.0 & 4.2 & 8.9 & 38.0 \\
\hline 150 & 0.5 & 3.5 & 45.6 & 0.0 & 4.3 & 9.2 & 37.4 \\
\hline \multicolumn{8}{|c|}{ Variance Decomposition of LSNG: } \\
\hline Period & S.E. & LBSE & LHNK & LSNG & LJP & LUK & LUS \\
\hline 1 & 0.0 & 0.0 & 21.2 & 40.3 & 3.8 & 3.9 & 30.8 \\
\hline 4 & 0.1 & 1.1 & 16.8 & 32.1 & 5.2 & 6.7 & 38.2 \\
\hline 12 & 0.2 & 2.9 & 16.2 & 26.3 & 7.0 & 9.6 & 38.1 \\
\hline 52 & 0.3 & 5.0 & 16.9 & 22.8 & 8.1 & 12.7 & 34.5 \\
\hline 150 & 0.6 & 5.5 & 17.1 & 22.1 & 8.4 & 13.4 & 33.5 \\
\hline \multicolumn{8}{|c|}{ Variance Decomposition of LJP: } \\
\hline Period & S.E. & LBSE & LHNK & LSNG & LJP & LUK & LUS \\
\hline 1 & 0.0 & 0.0 & 0.0 & 0.0 & 78.1 & 1.3 & 20.6 \\
\hline 4 & 0.1 & 0.1 & 0.2 & 0.5 & 69.0 & 0.7 & 29.6 \\
\hline 12 & 0.1 & 0.1 & 0.2 & 1.1 & 61.9 & 0.5 & 36.3 \\
\hline 52 & 0.2 & 0.5 & 0.2 & 0.9 & 56.4 & 0.1 & 41.8 \\
\hline 150 & 0.4 & 0.6 & 0.3 & 0.9 & 55.1 & 0.1 & 43.1 \\
\hline \multicolumn{8}{|c|}{ Variance Decomposition of LUK: } \\
\hline Period & S.E. & LBSE & LHNK & LSNG & LJP & LUK & LUS \\
\hline 1 & 0.0 & 0.0 & 0.0 & 0.0 & 0.0 & 34.4 & 65.6 \\
\hline 4 & 0.0 & 0.3 & 0.2 & 0.0 & 0.1 & 29.0 & 70.5 \\
\hline 12 & 0.1 & 0.8 & 0.1 & 0.1 & 0.1 & 30.8 & 68.1 \\
\hline 52 & 0.2 & 2.0 & 0.2 & 0.2 & 0.2 & 35.7 & 61.8 \\
\hline 150 & 0.3 & 2.3 & 0.2 & 0.3 & 0.2 & 36.9 & 60.1 \\
\hline \multicolumn{8}{|c|}{ Variance Decomposition of LUS: } \\
\hline Period & S.E. & LBSE & LHNK & LSNG & LJP & LUK & LUS \\
\hline 1 & 0.0 & 0.0 & 0.0 & 0.0 & 0.0 & 0.0 & 100.0 \\
\hline 4 & 0.0 & 1.2 & 0.1 & 0.0 & 0.0 & 1.0 & 97.6 \\
\hline 12 & 0.1 & 5.4 & 0.3 & 0.3 & 0.3 & 5.7 & 88.1 \\
\hline 52 & 0.2 & 12.8 & 0.8 & 1.1 & 0.8 & 12.6 & 72.0 \\
\hline 150 & 0.3 & 14.8 & 0.9 & 1.3 & 0.9 & 14.4 & 67.6 \\
\hline
\end{tabular}


Table 8B. Variance Decomposition: April 1993 to January 18, 2008

\begin{tabular}{|c|c|c|c|c|c|c|c|}
\hline \multicolumn{8}{|c|}{ Variance Decomposition of LBSE } \\
\hline Period & S.E. & LBSE & LHNK & LSNG & LJP & LUK & LUS \\
\hline 1 & 0.0 & 88.0 & 3.0 & 0.6 & 1.3 & 2.6 & 4.5 \\
\hline 4 & 0.1 & 75.5 & 6.3 & 0.1 & 2.1 & 6.2 & 9.8 \\
\hline 12 & 0.1 & 61.5 & 13.1 & 0.1 & 1.7 & 11.4 & 12.1 \\
\hline 52 & 0.3 & 51.3 & 18.2 & 0.3 & 2.1 & 17.3 & 10.8 \\
\hline 150 & 0.5 & 48.9 & 19.4 & 0.3 & 2.3 & 18.8 & 10.3 \\
\hline \multicolumn{8}{|c|}{ Variance Decomposition of LHNK } \\
\hline Period & S.E. & LBSE & LHNK & LSNG & LJP & LUK & LUS \\
\hline 1 & 0.0 & 0.0 & 63.5 & 0.0 & 2.5 & 5.7 & 28.2 \\
\hline 4 & 0.1 & 0.7 & 57.4 & 0.0 & 3.1 & 7.7 & 31.1 \\
\hline 12 & 0.1 & 1.3 & 55.9 & 0.1 & 2.9 & 6.8 & 33.0 \\
\hline 52 & 0.3 & 1.0 & 54.3 & 0.3 & 2.7 & 5.6 & 36.1 \\
\hline 150 & 0.5 & 0.9 & 54.0 & 0.3 & 2.6 & 5.3 & 36.9 \\
\hline \multicolumn{8}{|c|}{ Variance Decomposition of LSNG: } \\
\hline Period & S.E. & LBSE & LHNK & LSNG & LJP & LUK & LUS \\
\hline 1 & 0.0 & 0.0 & 24.3 & 45.7 & 4.0 & 4.3 & 21.6 \\
\hline 4 & 0.1 & 0.7 & 21.7 & 37.7 & 5.6 & 9.1 & 25.2 \\
\hline 12 & 0.1 & 2.0 & 21.5 & 33.8 & 7.1 & 11.0 & 24.6 \\
\hline 52 & 0.3 & 2.8 & 21.8 & 31.8 & 8.0 & 12.2 & 23.4 \\
\hline 150 & 0.5 & 3.0 & 21.8 & 31.4 & 8.1 & 12.5 & 23.1 \\
\hline \multicolumn{8}{|c|}{ Variance Decomposition of LJP: } \\
\hline Period & S.E. & LBSE & LHNK & LSNG & LJP & LUK & LUS \\
\hline 1 & 0.0 & 0.0 & 0.0 & 0.0 & 81.8 & 1.9 & 16.4 \\
\hline 4 & 0.1 & 0.0 & 0.2 & 0.5 & 75.8 & 1.6 & 21.9 \\
\hline 12 & 0.1 & 0.6 & 0.7 & 0.9 & 67.6 & 0.9 & 29.3 \\
\hline 52 & 0.2 & 2.5 & 1.3 & 0.5 & 58.6 & 0.2 & 37.0 \\
\hline 150 & 0.4 & 3.0 & 1.4 & 0.4 & 56.5 & 0.1 & 38.7 \\
\hline \multicolumn{8}{|c|}{ Variance Decomposition of LUK: } \\
\hline Period & S.E. & LBSE & LHNK & LSNG & LJP & LUK & LUS \\
\hline 1 & 0.0 & 0.0 & 0.0 & 0.0 & 0.0 & 45.5 & 54.5 \\
\hline 4 & 0.0 & 0.1 & 0.2 & 0.0 & 0.2 & 46.4 & 53.1 \\
\hline 12 & 0.1 & 0.4 & 0.1 & 0.3 & 0.2 & 45.7 & 53.3 \\
\hline 52 & 0.1 & 0.5 & 0.1 & 0.4 & 0.3 & 45.7 & 53.0 \\
\hline 150 & 0.2 & 0.6 & 0.1 & 0.4 & 0.3 & 45.7 & 53.0 \\
\hline \multicolumn{8}{|c|}{ Variance Decomposition of LUS: } \\
\hline Period & S.E. & LBSE & LHNK & LSNG & LJP & LUK & LUS \\
\hline 1 & 0.0 & 0.0 & 0.0 & 0.0 & 0.0 & 0.0 & 100.0 \\
\hline 4 & 0.0 & 1.2 & 0.0 & 0.0 & 0.1 & 3.2 & 95.4 \\
\hline 12 & 0.1 & 6.5 & 0.0 & 0.6 & 0.1 & 7.9 & 84.8 \\
\hline 52 & 0.1 & 13.6 & 0.1 & 1.6 & 0.1 & 13.4 & 71.2 \\
\hline 150 & 0.2 & 15.4 & 0.2 & 1.9 & 0.1 & 14.7 & 67.8 \\
\hline
\end{tabular}


(which included the global crisis phase), it was evident that global and regional markets accounted for about four-fifth of the total variation in India's stock price index over one year horizon. The remaining one-fifth of the total variation in India's stock market could be attributable to its own innovation or the secular component. On the other hand, for the restricted sample (excluding the crisis phase), it was found that global and regional markets were able to account for about half of the total variation in India's stock market. Across the markets, the impact of global markets on India had almost doubled due to the global crisis. Among the regional markets, the impact of Hong Kong showed some marginal improvement. These results suggested that the global crisis had accentuated risk pricing and thus, India's integration with global and regional markets. As compared with other regional markets, it was evident that Hong Kong had a more or less similar dependence on the US and UK markets. Singapore and Japan were more dependent on the US and the Hong Kong markets. The US market accounted for the bulk of variation in the UK market. Finally, for the US market, its own innovation or domestic factors could have played a dominant role.

\section{Conclusion}

The study engaged in an analysis of the integration of India's stock market with global and major regional stock markets before and after the global crisis. To begin with, deriving from the key concerns of the EMEs and various theoretical and applied finance perspectives, the study stressed that it is useful for policy purposes to adhere to a positive perspective on the subject of international integration amid the global crisis. Financial integration and its association with the global crisis could be construed in terms of the pricing of risks by the markets. The empirical evidence more or less supported the above perspective. We found several interesting insights about the integration of the Indian stock market. It assumed critical importance for the international integration among select regional and global stock markets. A key finding of the study was that the Indian market was integrated with regional and global markets in terms of stock prices measured in US dollar but not local currencies, a finding attributable to role of foreign investors participating in the Indian market. Regional and global stock markets had differential impact on the Indian market in the long run as well as the short run. In terms of the long-run cointegration relation, India's dependence on the global markets, such as the United States and the United Kingdom, was substantially 
higher than on regional markets such as Singapore and Hong Kong. The global crisis did not throw away the cointegration among the stock markets. It had a moderating impact, albeit, marginally, on the long-run coefficients pertaining to the integration among the regional and global markets studied here. The innovation accounting in the cointegration model showed that regional and global markets together accounted for the bulk of total variation in the Indian stock market, implying that the global crisis could have accentuated the re-pricing of the risks. The long run impact of two global markets, the United States and the United Kingdom, on the Indian market was in the opposite direction. Within Asia, Singapore and Hong Kong markets had a significant influence, while the Japanese market had a weak influence on the Indian market. Thus, from policy perspective, cointegrated stock markets may contribute to financial stability as they are not expected to deviate too far from the long-run path. In terms of portfolio diversification, investors cannot benefit from arbitrage activities in the long run. In the short run, however, markets would be influenced by the diversification objective of foreign investors. According to the literature, such opportunities for diversification may contribute to price discovery process and not destabilize the markets. To sum up, it is useful to adhere to a risk pricing perspective on financial integration and continue with measures to strengthen the integration process in the future. The lack of integration among stock prices in terms of local currency gives rise to a concern that India's stock market integration may not be a complete process, attributable, inter alia, to the inadequate role of domestic investors.

\section{Acknowledgements}

The author is thankful to Dr. Eli Remonala, Head of Economics, Bank for International Settlement, Hong Kong Office, for useful suggestions on an earlier version of the paper presented in the Asian Research Conference held in January 2008 at Hong Kong under the aegis of Hong Kong Monetary Authority and Bank for International Settlement. The views expressed in the paper are solely of the author, not the organisation to which the author belongs.

Received 05 September 2008, Revised 26 August 2009, Accepted 27 August 2009 


\section{Annex: Stock Price Data Definition}

\begin{tabular}{|c|c|c|c|c|}
\hline Country & $\begin{array}{l}\text { Stock price symbol } \\
\text { used in the study } \\
\text { (natural logarithm } \\
\text { scale) }\end{array}$ & $\begin{array}{c}\text { Thomson } \\
\text { Financial Inc.'s } \\
\text { Datastream } \\
\text { Symbol (us dol- } \\
\text { lar prices) }\end{array}$ & $\begin{array}{l}\text { Description of the stock } \\
\text { indices }\end{array}$ & $\begin{array}{l}\text { Original Data Pro- } \\
\text { vider }\end{array}$ \\
\hline India & BSE (LBSE) & IBOMDLX & $\begin{array}{l}\text { BSE Dollex - the 200- } \\
\text { scrip BSE Index in US } \\
\text { dollar terms }\end{array}$ & $\begin{array}{l}\text { Bombay Stock } \\
\text { Exchange }\end{array}$ \\
\hline Singapore & SNG (LSNG) & SBBSNG\$ & $\begin{array}{l}\text { Broad Market Index in } \\
\text { US dollar terms }\end{array}$ & S \&P Citi Group \\
\hline Hong Kong & HK (LHK) & SBBHNK\$ & $\begin{array}{l}\text { Broad Market Index in } \\
\text { US dollar terms }\end{array}$ & S \&P Citi Group \\
\hline Japan & JP (LJP) & TOTMJP\$ & $\begin{array}{l}\text { Broad market index in } \\
\text { US dollar terms }\end{array}$ & Datastream \\
\hline $\begin{array}{l}\text { United King- } \\
\text { dom }\end{array}$ & UK (LUK) & SBBUKD\$ & $\begin{array}{l}\text { Broad Market Index in } \\
\text { US dollar terms }\end{array}$ & S \&P Citi Group \\
\hline United States & NYSE (LNYSE) & NYSEALL & $\begin{array}{l}\text { NYSE COMPOSITE - } \\
\text { PRICE INDEX }\end{array}$ & NYSE \\
\hline
\end{tabular}

Note: 1. For each of the variable with the prefix ' $\mathrm{D}$ ' denotes for first difference series. Illustratively, DLBSE refers to first difference of natural logarithm transformed stock price index in India, as defined in the above. The datastream provides the above stock price idniecs in local currency.

2. In order to account for differential time zones in respect of global markets and regional markets, stock prices of the US and UK markets are lagged by 1-day.

\section{References}

Agenor, P. R.(2001), "Benefits and Costs of International Financial Integration: Theory and Facts", World Bank Policy Research Working Paper No. 2699.

Agmon T.(1972), "The Relationship among Equity Markets: a Study of Share Price Comovement in the United States, United Kingdom, Germany and Japan", Journal of Finance, 27(3), pp. 839-855.

Ahlgren N. and Antell J.(2002), "Testing for Cointegration between International Stock Prices", Applied Financial Economics, 12(12), pp. 851-866.

Bachman D., Jongmoo J. C., Jeon B. N., Kenneth J. K.(1996), "Common Factors in International Stock Prices: Evidence from Cointegration Study", International Review of Financial Analysis, 5(1), pp. 39-53.

Baillie R. T. and Bollerslev T.(1989), "Common Stochastic Trends in a System of Exchange Rates", Journal of Finance, 44(1), pp. 167-181.

Blackman K., Holden K. and Thomas W.(1994), "Long-Term Relationships between International Share Prices", Applied Financial Economics, 4(4), pp. 297-304.

Byers J. D. and Peel D. A.(1993), "Some Evidence on the Interdependence of National Stock Markets and the Gains from International Portfolio Diversification", Applied 
Financial Economics, 3(3), pp. 239-242.

Cha B. and Oh S.(2000), "The Relationship between Developed Equity Markets and the Pacific Basin's Emerging Equity Markets", International Review of Economics and Finance, 9(4), pp. 299-322.

Chen G. M., Firth M. and Rui O. M.(2002), "Stock Market Linkages: Evidence from Latin America", Journal of Banking and Finance, 26(6), pp. 1113-1141.

Chowdhry A. R.(1994), "Stock Market Interdependencies: Evidence from the Asian NIEs", Journal of Macroeconomics, 16(4), pp. 629-651.

Choudhry T., Lin L. and Peng K.(2007), "Common Stochastic Trends among Far Eastern Stock Prices: Effects of Asian Financial Crisis”, International Review of Financial Analysis, 16(3), pp. 242-261.

Cournot A.(1927), Researches into the Mathematical Principles of the Theory of Wealth, Trans. by Nathaniel T Bacon, Macmillan, New York.

Crowder W. J. and Wohar M. E.(1998), "Cointegration, Forecasting and International Stock Prices”, Global Finance Journal, 9(2), pp. 181-204.

Dickey D. A., Jansen D. W. and Thornton D. L.(1991), “A Primer on Cointegration with an Application to Money and Income", Cointegration for Applied Economist, Rao B B (Editor), New York, St Martin Press.

Dwyer G. P. J. and Wallace M. S.(1992), "Cointegration and Market Efficiency”, Journal of International Money and Finance, 11(6), pp. 318-327.

Engle R. F. and Granger C. W. J.(1987), "Cointegration and Error Correction: Representation, Estimation, and Testing”, Econometrica, 55(2), pp. 251-276.

Eun C. S. and Shim S.(1989), "International Transmission of Stock Market Movements", Journal of Financial and Quantitative Analysis, 24(2), pp. 241-256.

Gonzallo J. and Granger C. W. J.(1995), "Estimation of Common Long-Memory Components in Cointegrated Systems", Journal of Business and Economic Statistics, 13(1), pp. 27-35.

Granger, C. W. J.(1992), "Forecasting Stock Market Prices: Lessons for Forecasters", International Journal of Forecasting, 8, pp. 3-13.

Granger C. W. J.(1986), "Developments in the Study of Cointegrated Economic Variables", Oxford Bulletin of Economics and Statistic, 48(3), pp. 213-228.

Hakkio C. S. and Rush M.(1989), "Market Efficiency and Cointegration: an Application to the Steling and Deutschemark Exchange Markets", Journal of International Money and Finance, 8(1), pp. 75-88.

Hakkio, C. S., \& Rush, M.(1991), “Cointegration: How Short Is the Long Run?”, Journal of International Money and Finance, 10(4), pp. 571-581.

Harvey C. R.(1995), "Predictable Risk and Returns in Emerging Markets", Review of Financial Studies, 8(3), pp. 773-816.

Hassan M. K. and Naka A.(1996), "Short-Run and Long-Run Dynamic Linkages among International Stock Markets", International Review of Economics and Finance, 5(4), pp. 387-405.

Hilliard J.(1979), “The Relationship between Equity Indices on World Exchanges”, 
Journal of Finance, 34(1), pp. 103-114.

Johansen S.(1988), "Statistical Analysis of Cointegrating Vectors", Journal of Economic Dynamic and Control, 12(2-3), pp. 231-254.

Johansen S. and Juselius K.(1990), Maximum Likelihood Estimation and Inferences on Cointegration - with Applications to the Demand for Money, Oxford Bulletin of Economics and Statistics, 52(2), pp. 169-210.

Kasa K.(1992), “Common Stochastic Trends in International Stock Markets”, Journal of Monetary Economics, 29(1), pp. 95-124.

Kearney C. and Lucey B.(2004), "International Equity Market Integration: Theory, Evidence and Implications", International Review of Financial Analysis, 13(3),pp. 571-583.

Kim E. H. and V. Singhal(2000), "Stock Market Opening: Experience of Emerging Economies", Journal of Business, 73(1), pp. 25-66.

Korajczyk R. A. and Viallet C. J.(1989), “An Empirical Investigation of International Asset Pricing”, Review of Financial Studies, 2(4), pp. 553-585.

Korajczyk, R.(1996), “A Measure of Stock Market Integration for Developed and Emerging Markets”, The World Bank Economic Review,10, pp. 12-33.

Kunt, A. D. and L. Serven(2009), "Are All the Sacred Cows Dead? Implications of the Financial Crisis for Macro and Financial Policies", The World Bank Policy Research Working Paper, No. 4807.

Levine, Ross(2001) "International Financial Integration and Economic Growth", Review of International Economics, Vol. 9.

Levy H. and Sarnat M.(1970), "International Diversification of Investment Portfolios", American Economic Review, 60(4), pp. 668-675.

Lintner J.(1965), "Security Prices, Risk and Maximum Gains from Diversification", Journal of Finance, 20(4), pp. 587-616.

Markowitz H.(1952), "Portfolio Selection”, Journal of Finance, 7(1), pp. 77-91.

Marshall A.(1930), Principles of Economics, An Introductory Volume, 8th Edn, Macmillan, London.

Masih A. M. M. and Masih R.(1997), "Dynamic Linkages and the Propagation Mechanism Driving Major International Markets: an Analysis of the Pre-and PostCrash Areas", Quarterly Review of Economics and Finance, 37(4), pp. 859-885.

Masih A. M. M. and Masih R.(2002), "Propagative Causal Price Transmission Among International Stock Markets: Evidence from Pre- and Post-Globalisation Period, Global Finance Journal, 13(1), pp. 63-91.

Meric I. and Meric I.(1989), "Potential Gains from International Portfolio Diversification and Inter-Temporal Stability and Seasonality in International Stock Market Relationships", Journal of Banking and Finance, 13(6), pp. 627-640.

Mohan, R.(2006), "Monetary and Financial Policy Responses to Global Imbalances", RBI Bulletin, December.

Mohan, R.(2009), "Global Financial Crisis: Causes, Impact, Policy Responses and Lessons", Reserve Bank of India Bulletin, May, pp. 879-904. 
Obsfeld, M.(1998), "The Global Capital Market- Benefactor or the Menace?", Journal of Economic Perspectives, 12(4).

Panton D. B., Lessig V. P. and Joy O. M.(1976), "Comovement of International Equity Markets: a Taxonomic Approach", Journal of Financial and Quantitative Analysis, 11(3), pp. 415-432.

Philippatos G. C., Christofi A. and Christofi P.(1983), "The Inter-Temporal Stability of International Stock Market Relationships: Another View", Financial Management, Winter, 12(4), p. 63-69.

Prasad E. S., Kenneth R., Shang-Jin W. and Kose M. A.(2003), "Effects of Financial Globalization on Developing Countries: Some Empirical Evidence", IMF Occasional Paper No. 220, International Monetary Fund, Washington.

Prasad E. S., Kenneth R., Shang-Jin W. and Kose M. A.(2006), "The Macroeconomic Implications of Financial Globalisation", Journal of Economic Literature.

Renatas K. and Christian P.(2006), "Business-Cycle Fluctuations and International Equity Correlations", Global Finance Journal, 17(2), pp. 252-270.

Ross S.(1976), "The Arbitrage Theory of Capital Asset Pricing", Journal of Economic Theory, 13(3), pp. 341-360.

Schollhammer H. and Sand O. C.(1987), "Lead-Lag Relationships among National Equity Markets: An Empirical Investigation", in Khoury S J and Ghosh A (Editors), Recent Developments in International Banking and Finance, Lexington, MA.

Sephton P. S. and Larsen H. K.(1991), "Tests of Exchange Market Efficiency: Fragile Evidence from Cointegration Tests", Journal of International Money and Finance, 10(4), pp. 561-570.

Sharpe W.(1964), "Capital Asset Prices: a Theory of Market Equilibrium under Conditions of Risk", Journal of Finance, 19(3), pp. 425-442.

Solnik, B. H.(1974), "The International Pricing of Risk: an Empirical Investigation of the World Capital Market Structure", Journal of Finance, 29, pp. 365-378.

Solnik B., Boucrelle C. and Le F. Y.(1996), "International Market Correlation and Volatility”, Financial Analysts Journal, 52(5), pp. 17-34.

Taylor M. P. and Tonks I.(1989), "The Internationalization of Stock Markets and Abolition of UK Exchange Control", Review of Economics and Statistics, 71(2), pp. 332-336.

Trichet, Jean-Claude(2009), 'Under-pricing of Risks in the Financial Sector', Speech by President of the ECB Delivered at the Coface Country Risk Conference 2009, Carrousel du Louvre,Paris, 19 January 2009

Verchenko O.(2000), "Potential for Portfolio Diversification across Eastern European Stock Markets", Master Thesis, National University Kiev-Mohyla Academy.

Voronkova S.(2004), "Equity Market Integration in Central European Emerging Markets: a Cointegration Analysis with Shifting Regimes", International Review of Financial Analysis, 13(5), pp. 633-647.

Watanagase, T.(2008), "Global Financial Crisis and Economic Integration in Asia”, Bank for International Settlement, Switzerland, Central Bank Speeches. 
Worthington, A. C. and Higgs, H.(2007), "Evidence of Financial Integration in Asia: an Empirical Application of Panel Unit Root Tests and Multivariate Cointegration and Causality Procedures", University of Wollongong, Working Paper Series.

Yu I., Fung L. and Tam C.(2007), "Assessing Financial Market Integration in Asia-Equity Markets", Working Paper 04/2007, Hong Kong Monetary Authority. 